\title{
PENGARUH CORPORATE GOVERNANCE TERHADAP KINERJA PERUSAHAAN MANUFAKTUR
}

\author{
RHETNO WULANSARI ${ }^{\mathrm{a}}$ \\ ANDRY IRWANTO ${ }^{b}$ \\ ${ }^{a}$ Sekolah Pascasarjana Universitas Airlangga ${ }^{b}$ Fakultas Ekonomi dan Bisnis Universitas Airlangga \\ Email: rhetnowulansari@yahoo.com ; andryirwanto149@gmail.com ${ }^{b}$
}

ARTICLE HISTORY

Received:

19 Februari 2018

Revised

16 March 2018

Accepted:

1 April 2018

Online available:

30 Mei 2018

Keywords:

Insider Ownership,

Audit Committees,

Leverage,

Firm Size, Independent

Commissioners,

Performance

Companies

Kata kunci:

insider ownership, komite audit, leverage, firm size, jumlah komisaris independen, kinerja perusahaan.

\section{ABSTRACT}

Introduction: This study aims to determine the effect of insider ownership, audit committees, leverage, firm size, the number of independent commissioner on the performance of manufacturing firms in the Indonesian stock exchange.

Methods: The type of data used in this research is quantitative data. This study uses a tool to answer the hypothesis in the form of multiple linear regression. The number of samples taken by the sampling technique as many as 50 companies listed in Indonesia Stock Exchange.

Results: From the test results indicate that there is insider ownership, audit committees, leverage significant positive effect on the performance of manufacturing companies in Indonesia Stock Exchange. firm size and the number of independent commissioners no significant positive effect on the performance of manufacturing companies in Indonesia Stock Exchange.

Conclusion and suggestion: The implication of these findings is that insider ownership, audit committees, and leverage it will be able to produce a good performance. Although firm size and the number of independent commissioners has no effect, but still must be considered, because if the firm size and the number of independent commissioners are not in accordance with the provisions of SFAS may result in the presence of certain interests that are not in accordance with the company's goals. 


\begin{abstract}
ABSTRAK
Penelitian ini bertujuan untuk mengetahui pengaruh insider ownership, komite audit, leverage, firm size, jumlah komisaris independen terhadap kinerja perusahaan manufaktur di bursa efek Indonesia. Populasi yang digunakan dalam penelitian ini adalah perusahaan manufaktur yang terdaftar di Bursa Efek Indonesia tahun 2011-2013 sebanyak 131 perusahaan. Teknik pengambilan sampel pada penelitian ini menggunakan random sampling/probability sampling yaitu cara pengambilan sampel yang memberikan kesempatan yang sama kepada setiap elemen populasi untuk dijadikan sampel, dengan cara mencari ringkasan laporan keuangan setiap perusahaan manufaktur dan harga saham aktif di perdagangkan di Bursa Efek Indonesia mulai tahun 2010 hingga 2013, sehingga jumlah sampel yang diambil berdasarkan teknik sampling tersebut sebanyak 50 perusahaan manufaktur yang terdaftar di Bursa Efek Indonesia. Jenis data yang digunakan dalam penelitian ini adalah data kuantitatif. Penelitian ini menggunakan alat bantu untuk menjawab hipotesis yaitu berupa regresi linier berganda.

Dari hasil pengujian menunjukkan bahwa terdapat insider ownership, komite audit, leverage berpengaruh positif signifikan terhadap kinerja perusahaan manufaktur di Bursa Efek Indonesia. firm size dan jumlah komisaris independen berpengaruh positif tidak signifikan terhadap kinerja perusahaan manufaktur di Bursa Efek Indonesia. Implikasi dari temuan tersebut adalah bahwa insider ownership, komite audit, dan leverage maka akan mampu menghasilkan kinerja perusahaan yang baik. Meskipun firm size dan jumlah komisaris independen tidak berpengaruh, namun tetap harus diperhatikan, karena apabila firm size dan jumlah komisaris independen tidak sesuai dengan ketentuan PSAK akan dapat mengakibatkan adanya kepentingan-kepentingan tertentu yang tidak sesuai dengan tujuan perusahaan.
\end{abstract}

\title{
INTRODUCTION
}

Corporate governance merupakan tata kelola perusahaan yang menjelaskan hubungan antara berbagai partisipan dalam perusahaan yang menentukan arah kinerja perusahaan. Pada awalnya Corporate Governance lahir sebagai prinsip-prinsip dan nilainilai yang harus dikembangkan oleh perusahaan agar tetap survive, karena menyangkut prinsip dan nilai tersebut maka dalam prakteknya Corporate Governance muncul di tiap negara dengan isu yang berbeda-beda disesuaikan dengan sistem ekonomi yang ada di setiap negara. Selain itu dalam prakteknya, agar dapat dilaksanakan, prinsip dan nilai Corporate Governance harus disesuaikan dengan kondisi yang ada pada suatu perusahaan dan sangat tergantung dengan bentuk perusahaan, jenis usaha dan komposisi kepemilikan modal perusahaan. 
Peran dan tuntutan investor dan kreditor asing mengenai penerapan prinsip GCG merupakan salah satu faktor dalam pengambilan keputusan berinvestasi pada suatu perusahaan. Penerapan prinsip GCG dalam dunia usaha di Indonesia merupakan tuntutan zaman agar perusahaan-perusahaan yang ada jangan sampai terlindas oleh persaingan global yang semakin keras. Prinsip-prinsip dasar dari Good Corporate Governance (GCG) pada dasarnya memiliki tujuan untuk memberikan kemajuan terhadap kinerja suatu perusahaan (Effendi, 2008). Rendahnya corporate governance membuat hubungan investor dan perusahaan menjadi lemah, kurangnya tingkat transparansi, terjadi ketidak efisienan dalam laporan keuangan, dan lemahnya penegakan hukum atas perundang-undangan dalam menghukum pelaku dan melindungi pemegang saham minoritas, menjadi pemicu dan alasan runtuhnya beberapa perusahaan di Indonesia (Hardikasari, 2011).

Corporate governance lebih condong pada serangkaian pola perilaku perusahaan yang diukur melalui kinerja, pertumbuhan, struktur pembiayaan, perlakuan terhadap para pemegang saham, dan stakeholders sehingga dapat dijadikan sebagai dasar analisis dalam mengkaji corporate governance di suatu negara dengan memenuhi transparansi dan akuntabilitas dalam pengambilan keputusan yang sistematis yang dapat digunakan sebagai dasar pengukuran yang lebih akurat mengenai kinerja perusahaan dan bagaimana korelasi antar kebijakan tentang buruh dan kinerja perusahaan (Azhar, 2010).

Kinerja perusahaan dapat dilihat dari kondisi keuangan perusahaan. Kondisi keuangan perusahaan dapat dilihat melalui analisis rasio-rasio keuangannya. Bagi sebagian besar investor, laporan keuangan yang diungkapkan secara transparan dan akurat menjadi salah satu bahan masukan yang penting untuk memutuskan apakah mereka akan menginvestasi atau meminjamkan dananya kepada perusahaan tertentu. Perusahaan meyakini bahwa penerapan corporate governance merupakan bentuk lain penegakan etika bisnis dan etika kerja yang sudah lama menjadi komitmen perusahaan dan penerapan corporate governance berhubungan dengan peningkatan citra perusahaan. Perusahaan yang mempraktikkan corporate governance, akan mengalami perbaikan citra, dan peningkatan nilai perusahaan (Muchamad, 2012).

Mekanisme pengendalian corporate governance secara internal sangatlah penting, hal ini untuk mengetahui kinerja perusahaan dilihat dari laporan keuangan, para pemegang saham dan struktur dewan yang dimiliki perusahaan. Berdasarkan penelitian terdahulu yang menguji pengaruh corporate governance berpengaruh positif terhadap kinerja perusahaan adalah penelitian Krishna et al. (2010) terbukti insider ownership berpengaruh positif signifikan terhadap kinerja perusahaan. Waseem et al. (2011) dan Zubaidah et al. (2009) terbukti leverage dan ukuran perusahaan berpengaruh positif signifikan terhadap kinerja perusahaan. Husam et al. (2012) terbukti firm size berpengaruh positif signifikan terhadap kinerja perusahaan. Fuerst dan Kang (2004) 
menguji corporate governance dan kinerja perusahaan, menunjukkan adanya hubungan positif antara jumlah komisaris independen dengan kinerja perusahaan.

Berdasarkan penelitian terdahulu yang menguji pengaruh corporate governance berpengaruh negatif terhadap kinerja perusahaan adalah penelitian Krishna et al. (2010) terbukti komite audit, leverage, dan ukuran perusahaan berpengaruh negatif signifikan terhadap kinerja perusahaan. Zunaidah et al. (2013) terbukti leverage, kualitas audit, managerial ownership dan ukuran perusahaan berpengaruh negatif signifikan terhadap kinerja perusahaan. Husam et al. (2012) terbukti leverage berpengaruh negatif signifikan terhadap kinerja perusahaan.

\section{LITERATURE REVIEW}

\section{The traditional society}

\section{Good Corporate Governance (GCG)}

Good Corporate Governance (GCG) dilandasi oleh agency theory dimana penerapan konsep ini diharapkan dapat melindungi pemegang saham dan kreditor dalam mendapatkan kembali investasinya. Sutedi (2011: 2), menjelaskan bahwa "Good Corporate Governance (GCG), secara definitif merupakan sistem yang mengatur dan mengendalikan perusahaan untuk menciptakan nilai tambah (value added) bagi semua stakeholder. Terdapat dua hal yang ditekankan dalam konsep ini, pertama pentingnya hak pemegang saham untuk memperoleh informasi dengan benar dan tepat pada waktunya. Kedua, kewajiban perusahaan untuk pengungkapkan (disclosure) secara akurat, tepat waktu, dan transparan terhadap semua informasi kinerja perusahaan, kepemilikan, dan stakeholder". Pendapat yang sama disampaikan oleh Zarkasyi (2008:38) yang menjelaskan bahwa: "GCG pada dasarnya merupakan suatu sistem (input, output, proses) dan seperangkat peraturan yang mengatur hubungan antara berbagai pihak yang berkepentingan (stakeholder), terutama dalam arti sempit hubungan atara pemegang saham, dewan komisaris, dan dewan direksi demi tercapainya tujuan perusahaan".

Perusahaan dengan praktik CG yang baik akan dapat meningkatkan nilai perusahaan bagi pemegang saham karena visi, misi dan strategi perusahaan dinyatakan dengan jelas, nilai-nilai perusahaan serta kode etik disusun untuk memastikan adanya kepatuhan seluruh jajaran perusahaan, terdapat kebijakan untuk menghindari benturan kepentingan dan transaksi dengan pihak ketiga yang tidak tepat, risiko perusahaan dikelola dengan baik dan terdapat sistem pengendalian dan monitoring yang baik (Price Waterhouse Coopers, 2000).

Berikut ini terdapat beberapa rasio yang terkait dengan pengukuran corporate governance perusahaan. 
Insider Ownership

Kepemilikan Manajerial (insider ownership) adalah sebuah ukuran persentase saham yang dimiliki oleh direksi, manajemen, dan komisaris ataupun setiap pihak yang terlibat secara langsung dalam pembuatan keputusan perusahaan Sartono (2001). Pemilik perusahaan yang sekaligus menjadi pengelola perusahaan, semakin banyak saham yang dimiliki oleh insider ownership maka pihak manajemen cenderung menahan pembayaran dividen (Taswan, 2003). Manfaat-manfaat dari insider ownership akan sebagian atau seluruhnya terhapuskan oleh biaya-biaya untuk membujuk para manajer untuk tidak mendiversifikasikan (maldiversity) kekayaan mereka. Keengganan resiko manajerial dan pembatasan-pembatasan pada manajerial membatasi kemauan dan kemampuan para manajer untuk menjadi pemilik, sehingga akan membatasi suplai insider ownership. Para manajer yang enggan beresiko (risk averse) akan mengambil suatu posisi yang lebih besar dalam suatu perusahaan hanya jika perusahaan tersebut menghasilkan rate of return yang lebih tinggi sehingga dapat mengkompensasi resiko yang muncul. Batasan pada kekayaan manajerial berakibat menimbulkan biaya yang lebih tinggi bagi para manajer untuk mengontrol kepentingan/andil dalam perusahaanperusahaan besar. Menurut Krishna et al (2010) untuk menghitung insider ownership dapat dirumuskan sebagai berikut:

$$
\mathrm{IO}=\frac{\text { Jumlah Saham yg dimiliki direksi }}{\text { Jumlah Saham yg Beredar }} \times 100 \%
$$

Komite Audit

Komite Audit adalah sekelompok orang yang dipilih oleh kelompok yang lebih besar untuk mengerjakan pekerjaan tertentu atau untuk melakukan tugas-tugas khusus atau sejumlah anggota dewan komisaris perusahaan klien yang bertanggung jawab untuk membantu auditor dalam mempertahankan independensinya dari manajemen (Hiro Tugiman, 1995:8). Keputusan Ketua Bapepam Nomor: Kep-41/PM/2003 yang menyatakan bahwa komite audit adalah komite yang dibentuk oleh dewan komisaris dalam rangka membantu melaksanakan tugas dan fungsinya.

Badan pengawas Pasar modal (BAPEPAM) dalam surat edarannya (2003) mengatakan bahwa tujuan komite audit adalah membantu dewan komisaris untuk:

1. Meningkatkan kualitas laporan keuangan

2. Menciptakan iklim disiplin dan pengendalian yang didapat mengurangi kesempatan terjadinya penyimpangan dalam pengelolaan perusahaan.

3. Meningkatkan efektivitas fungsi audit internal dan eksternal audit.

4. Mengidentifikasi hal-hal yang memerlukan perhatian dewan komisaris.

Menurut Djuitaningsih dan Marsyah (2012) jumlah komite audit dapat diukur dengan rumus sebagai berikut:

$$
\mathrm{KA}=\sum \text { Komite Audit }
$$




\section{Leverage}

Rasio leverage digunakan untuk mengukur kemampuan perusahaan memenuhi kewajiban-kewajiban jangka panjangnya. Rasio leverage juga menyangkut struktur keuangan perusahaan, struktur keuangan adalah bagaimana perusahaan mendanai aktivitasnya. Biasanya, aktivitas perusahaan didanai dengan hutang jangka pendek dan modal pemegang saham. Ada beberapa macam rasio leverage, antara lain debt ratio (debt to total asset), debt to equity ratio, long term debt to equity, dan time interested earned. Namun, penelitian ini hanya berfokus pada debt to assets. Debt to total assets (DTA) menunjukkan beberapa bagian dari keseluruhan kebutuhan dana yang dibelanjai dengan utang atau beberapa bagian dari aktiva yang digunakan untuk menjamin utang. Kredit lebih menyukai rasio hutang yang rendah karena semakin rendah rasio ini, maka semakin rendah perlindungan terhadap kreditur dalam peristiwa likuidasi. Disisi lain, pemegang saham akan menginginkan leverage yang lebih besar karena dapat meningkatkan laba yang diharapkan. Menurut Krishna et al (2010) untuk menghitung leverage dirumuskan sebagai berikut:

$\mathrm{LEV}=\frac{\text { Total Hutang }}{\text { Total Aset }} \times 100 \%$

\section{Firm Size}

Ukuran perusahaan (firm size) adalah salah satu kriteria yang dipertimbangkan oleh investor dalam strategi berinvestasi. Ukuran perusahaan dapat digunakan sebagai alat untuk mengukur besar kecilnya perusahaan. Indikator yang dapat digunakan sebagai ukuran perusahaan adalah total penjualan, total aktiva, jumlah karyawan, value added, kapitalisasi nilai pasar dan berbagai parameter lainnya. Perusahaan pada pertumbuhan yang tinggi akan selalu membutuhkan modal yang semakin besar demikian juga sebaliknya perusahaan pada pertumbuhan penjualan yang rendah, kebutuhan terhadap modal juga semakin kecil maka, konsep tingkat pertumbuhan penjualan tersebut memiliki hubungan yang positif tetapi implikasi tersebut akan memberikan efek yang berbeda terhadap struktur modal yaitu dalam penentuan jenis modal yang digunakan. Pada perusahan yang besar di mana saham akan tersebar luas, setiap perluasan modal saham akan mempunyai pengaruh yang kecil terhadap terhadap hilangnya atau tergesernya pengendalian dari pihak yang dominan terhadap pihak yang bersangkutan (Riyanto, 2001: 299-300). Menurut Krishna et al. (2010) untuk menghitung ukuran perusahaan dapat dirumuskan dengan Ln total aset.

Komisaris Independen

Komisaris independen adalah anggota dewan komisaris yang tidak berafiliasi dengan manajemen, anggota dewan komisaris lainnya dan pemegang saham pengendali, serta bebas hubungan bisnis atau hubungan lainnya yang dapat mempengaruhi kemampuannya untuk bertindak independen atau bertindak semata-mata demi 
kepentingan perusahaan. Secara langsung keberadaan komisaris independen menjadi penting, karena didalam praktek sering ditemukan transaksi yang mengandung benturan kepentingan yang mengabaikan kepentingan pemegang saham publik (pemegang saham minoritas) serta stakeholder lainnya, terutama pada perusahaan di Indonesia yang menggunakan dana masyarakat didalam pembiayaan usahanya. Untuk lebih memantapkan efektifitas komisaris independen, jumlah komisaris independen dalam satu perusahaan ditetapkan paling sedikit 30\% dari jumlah seluruh komisaris atau paling sedikit 1 (satu) orang. Menurut Peraturan Pencatatan nomor IA tentang Ketentuan Umum Pencatatan Efek bersifat Ekuitas di Bursa yaitu jumlah komisaris independen minimum $30 \%$. Dalam rangka penyelenggaraan pengelolaan perusahaan yang baik (good corporate governance), perusahaan tercatat wajib memiliki komisaris independen yang jumlahnya proporsional sebanding dengan jumlah saham yang dimiliki oleh bukan pemegang saham pengendali dengan ketentuan jumlah komisaris independen sekurangkurangnya 30\% dari jumlah seluruh anggota komisaris (Kusumaning, 2004). Menurut Krishna et al (2010) untuk mengukur komisaris independen diukur dengan proporsi antara antara jumlah komisaris independen dengan seluruh total anggota dewan komisaris perusahaan.

\section{Kinerja Perusahaan}

Menurut Fauzi (1995:207) "Kinerja merupakan suatu istilah umum yang digunakan untuk sebagian atau seluruh tindakan atau aktivitas dari suatu organisasi pada suatu periode, seiring dengan referensi pada sejumlah standar seperti biaya-biaya masa lalu atau yang diproyeksikan, suatu dasar efisiensi, pertanggungjawaban atau akuntabilitas manajemen dan semacamnya". Menurut Mulyadi (2001:337) "Kinerja adalah keberhasilan personil, tim, atau unit organisasi dalam mewujudkan sasaran strategik yang telah ditetapkan sebelumnya dengan perilaku yang diharapkan". Pengukuran kinerja dapat didefinisikan sebagai proses pengkuantifikasian efisiensi dan efektivitas dari tindakan yang lalu. Ukuran kinerja dapat didefinisikan sebagai sebuah parameter yang digunakan untuk mengkuantifikasi efisiensi dan/atau efektivitas dari tindakan yang lalu. Metrik kinerja adalah definisi dari cakupan, isi dan bagian-bagian komponen dari sebuah ukuran kinerja yang berbasis luas (Neely, 2002).

Menurut Krishna et al (2010) untuk mengukur kinerja perusahaan menggunakan Return On Asset (ROA). Return on Asset (ROA) merupakan salah satu rasio profitabilitas. Dalam analisis laporan keuangan, rasio ini paling sering disoroti, karena mampu menunjukkan keberhasilan perusahaan menghasilkan keuntungan. ROA mampu mengukur kemampuan perusahaan menghasilkan keuntungan pada masa lampau untuk kemudian diproyeksikan di masa yang akan datang. Asset atau aktiva yang dimaksud adalah keseluruhan harta perusahaan, yang diperoleh dari modal sendiri maupun dari modal asing yang telah diubah perusahaan menjadi aktiva-aktiva perusahaan yang digunakan untuk kelangsungan hidup perusahaan. Menurut Horne dan Wachowicz (2005:236) untuk menghitung Return on Asset dapat dirumuskan sebagai berikut: 
ROA $=\frac{\text { Laba Bersih Setelah Pajak }}{\text { Total Aktiva. }} x 100 \%$

\section{Previous Study and Hypothesis}

Penelitian oleh Karim (2013) menemukan bahwa kepemilikan manajerial memiliki pengaruh positif terhadap kinerja perusahaan yang berarti bahwa semakin besar jumlah kepemilikan manajerial akan meningkatkan nilai perusahaan. Peningkatan proporsi saham yang dimiliki oleh manajer dan direksi akan menurunkan kecenderungan adanya tindakan manipulasi yang berlebihan, sehingga dapat menyatukan kepentingan antara manajer dan pemegang saham (Nurhidayati et al. 2012). Menurut Faisal (2005), besar kecilnya jumlah kepemilikan saham manajerial dalam perusahaan dapat mengindikasikan adanya kesamaan kepentingan antara manajemen dengan shareholders. Semakin meningkatnya proporsi kepemilikan manajerial maka akan semakin baik kinerja perusahaan sehingga manajer akan termotivasi untuk meningkatkan kinerjanya untuk perusahaan. Berdasarkan kesimpulan tersebut dapat dirumuskan hipotesis:

H1: Terdapat Pengaruh Positif Antara Insider Ownership dan Kinerja Perusahaan Manufaktur Di Bursa Efek Indonesia

Komite audit sebagai salah satu mekanisme corporate governance mampu mengurangi praktek manipulasi dan kecurangan dengan menjunjung prinsip corporate governance, transparansi, fairness, tanggung jawab, dan akuntabilitas yang pada prosesnya menghambat praktek kecurangan dan manupulasi dalam perusahaan. Hal ini sesuai dengan Nasution dan Doddy (2007), bahwa keberadaan komite audit dapat menghambat terjadinya kecurangan dalam manajemen laba, namun tidak selaras dengan Paramita Sari Rika (2008), menyatakan bahwa keberadaan komite audit dalam sebuah perusahaan tidak berpengaruh terhadap manajemen laba. Klein (2002) dalam Siallagan dan Machfoedz (2006), memberikan bukti secara empiris bahwa perusahaan yang membentuk komite audit independen melaporkan laba dengan kandungan akrual diskresioner yang lebih kecil dibandingkan dengan perusahaan yang tidak membentuk komite audit independen. Kandungan discretionary accruals tersebut berkaitan dengan kualitas laba perusahaan. Berdasarkan kesimpulan tersebut dapat dirumuskan hipotesis:

H2: Terdapat Pengaruh Positif Antara Komite Audit dan Kinerja Perusahaan Manufaktur Di Bursa Efek Indonesia

Menurut Sartono (2011:267), “Berbagai rasio finansial dapat dipergunakan untuk mengukur risiko dalam hubungannya dengan perusahaan yang menggunakan leverage dalam struktur modalnya. Misalnya total debt to total asset ratio, debt to equity ratio, time interest earned ratio dan fixed charged coverage ratio". Debt Ratio mengukur berapa besar aktiva perusahaan yang dibiayai oleh kreditur. Semakin rendah rasio 
hutang maka semakin bagus kinerja perusahaan, artinya asset yang dimiliki perusahaan sebagian kecil dibiayai dari hutang. Begitu juga sebaliknya, semakin besar rasio ini maka semakin buruk kinerja perusahaan, artinya asset yang dimiliki perusahaan sebagian besar dibiayai dari hutang (Sartono, 2011:54). Namun menurut Modigliani-Miller dalam Sartono (2011:236), perusahaan yang memiliki leverage akan memiliki nilai lebih tinggi jika dibandingkan dengan perusahaan tanpa memiliki leverage. Kenaikan nilai perusahaan terjadi karena pembayaran bunga atas utang merupakan pengurangan pajak dan oleh karena itu laba operasi yang mengalir kepada investor menjadi semakin besar. Berdasarkan kesimpulan tersebut dapat dirumuskan hipotesis:

H3: Terdapat Pengaruh Positif Antara Leverage dan Kinerja Perusahaan Manufaktur Di Bursa Efek Indonesia

Ukuran perusahaan bisa dilihat dari total asset perusahaan. Menurut Basir (2003), perusahaan dengan total asset yang besar mencerminkan kemapanan perusahaan. Perusahaan yang sudah mapan biasanya kondisi keuangannya juga sudah stabil. Selain itu, ukuran bank yang besar lebih diinginkan karena memungkinkan bank menyediakan menu jasa keuangan yang lebih luas. Ukuran perusahaan yang besar diharapkan dapat meningkatkan skala ekonomi dan mengurangi biaya pengumpulan dan pemrosesan informasi. Hal senada juga diungkapkan Sudarmadji dan Sularto (2007), dimana perusahaan besar yang mempunyai sumber daya yang besar pula akan melakukan pengungkapan lebih luas dan mampu membiayai penyediaan informasi untuk keperluan internal. Informasi tersebut sekaligus menjadi bahan untuk keperluan pengungkapan informasi kepada pihak eksternal seperti investor dan kreditor, sehingga tidak memerlukan tambahan biaya yang besar untuk melakukan pengungkapan lebih luas. Dengan demikian, perusahaan yang besar mempunyai biaya produksi informasi yang lebih rendah daripada perusahaan kecil. Berdasarkan kesimpulan tersebut dapat dirumuskan hipotesis:

H4: Terdapat Pengaruh Positif Antara Firm Size dan Kinerja Perusahaan Manufaktur Di Bursa Efek Indonesia

Dewan komisaris adalah pihak yang berperan penting dalam menyediakan laporan keuangan perusahaan yang reliable. Keberadaan dewan komisaris mempunyai pengaruh terhadap kualitas laporan keuangan dan dipakai sebagai ukuran tingkat rekayasa yang dilakukan oleh manajer (Chtourou, dkk., 2001). Dewan komisaris menggambarkan puncak dari sistim pengendalian pada perusahaan besar, yang memiliki peran ganda yaitu peran untuk memonitor dan pengesahan (ratification). Fama dan Jensen (Kusumaning, 2004) menyatakan bahwa pengendalian keputusan yang efektif merupakan fungsi positif dari rasio dewan komisaris eksternal dengan total keanggotaan dewan komisaris. Dewan komisaris yang independen secara umum mempunyai pengawasan yang lebih baik terhadap manajemen, sehingga mempengaruhi 
kemungkinan kecurangan dalam menyajikan laporan keuangan yang dilakukan oleh manajer (Chtourou, dkk: 2001) atau dengan kata lain, semakin kompeten dewan komisaris maka semakin mengurangi kemungkinan kecurangan dalam pelaporan keuangan. Berdasarkan kesimpulan tersebut dapat dirumuskan hipotesis:

H5: Terdapat Pengaruh Positif Antara Jumlah Komisaris Independen dan Kinerja Perusahaan Manufaktur Di Bursa Efek Indonesia

\section{RESEARCH METHODS}

Jenis data yang digunakan dalam penelitian ini adalah data kuantitatif. Penelitian ini menggunakan alat bantu untuk menjawab hipotesis yaitu berupa regresi linier berganda. Sedangkan menurut sumbernya, data yang digunakan dalam penelitian ini menggunakan data sekunder. Data sekunder yang digunakan yaitu annual report yang diperoleh melalui situs resmi BEI (www.idx.co.id), serta website perusahaan-perusahaan terkait. Metode pengumpulan data dalam penelitian ini adalah metode dokumentasi dan kepustakaan. Dengan metode ini dokumen-dokumen pendukung dipelajari agar mendapatkan informasi yang dibutukan. Dokumen-dokumen tersebut antara lain annual report, jurnal, artikel maupun dokumen pendukung lainnya.

Populasi yang digunakan dalam penelitian ini adalah perusahaan manufaktur yang terdaftar di Bursa Efek Indonesia tahun 2010-2012 sebanyak 131 perusahaan. Setelah menetapkan populasi, maka langkah berikutnya adalah menetapkan sampel penelitian. Teknik pengambilan sampel pada penelitian ini menggunakan purposive sampling, yaitu teknik pengambilan sampel dengan kriteria tertentu. Kriterianya adalah perusahaan manufaktur, menerbitkan laporan keuangan secara berturut turut mulai tahun 2010 sampai tahun 2012 dan memiliki saham yang aktif diperdagangkan di Bursa Efek Indonesia. Metode pengambilan sampel menggunakan proportional sampling pada masing-masing kelompok perusahaan selama tahun 2009-2011. Sampel yang diambil berdasar ketentuan tersebut adalah $20 \% \times 131$ perusahaan = 26 perusahaan manufaktur yang sudah ditetapkan dalam kriteria.

\section{RESULT AND ANALYSIS}

Penelitian ini menggunakan jenis analisis regresi linear sederhana. Data yang telah terkumpul kemudian diolah dengan menggunakan program SPSS 11.1 (Statistical Program For Social). Hasil pengolahan data selengkapnya disajikan pada Tabel 1 berikut ini:

Tabel 1

Hasil Regresi

\begin{tabular}{cccc}
\multicolumn{4}{c}{ Hasil Regresi } \\
\hline Variabel & Koefisien Regresi & Beta & Probability \\
\hline
\end{tabular}

Published by University of Airlangga.

This is an open access article under the CC BY license (https://creativecommons.org/licenses/by-sa/4.0/) 


\begin{tabular}{lccc}
\hline Insider Ownership & 0,107 & 0,148 & 0,048 \\
Komite Audit & 3,493 & 0,176 & 0,019 \\
Leverage & 12,826 & 0,488 & 0,000 \\
Firm Size & 0,195 & 0,043 & 0,654 \\
Jum Komisaris Independen & 1,540 & 0,125 & 0,194 \\
\hline Konstanta & $=$ & 18,253 \\
\hline $\mathrm{R}^{2}$ & $=$ & 0,312 \\
\hline Multiple R & $=$ & 0,559 \\
\hline Probability & $=$ & 0,000 \\
\hline
\end{tabular}

Hasil pengolahan data tersebut jika disajikan dalam bentuk persamaan adalah sebagai berikut:

$$
Y=18,253+0,107 \mathrm{IO}+3,493 \mathrm{KA}+12,826 \mathrm{LEV}+0,195 \mathrm{UP}+1,540 \mathrm{KI}+\mathrm{e}
$$

\section{Pengaruh Antara Insider Ownership Terhadap Kinerja Perusahaan}

Insider ownership memiliki pengaruh terhadap kinerja perusahaan. Temuan lain mengindikasikan bahwa semakin besar jumlah kepemilikan saham oleh manajerial maka akan dijadikan pertimbangan bagi para investor yang menganggap bisa menekan adanya potensi agensi. Manajer cenderung mengambil keputusan untuk memajukan perusahaan dengan tujuan agar perusahaan mengalami pertumbuhan tinggi karena manajer menganggap perusahaan adalah miliknya, sehingga kepentingan- kepentingan yang merugikan perusahaan dapat ditekan. Kepentingan ini seringkali sejalan dengan keinginan pemegang saham. Semakin tinggi dividen yang dibagikan berarti semakin sedikit laba yang ditahan, akibatnya tingkat pertumbuhan perusahaan dalam pendapatan dan harga saham semakin meningkat. Perbedaan kepentingan antara manajer dan pemegang saham sangat mungkin terjadi, karena para pengambil keputusan tidak perlu menanggung risiko sebagai akibat adanya kesalahan dalam pengambilan keputusan bisnis. Keefektifan sistem monitoring yang dilakukan oleh manajerial terhadap aktifitas manajemen sangat tergantung pada kemampuan manajerial dalam memperkirakan apakah sasaran dan strategi perusahaan telah konsisten dengan tujuan atau kepentingan pemilik saham pada lingkungan yang ada. Kesulitan manajerial melakukan monitoring terhadap manajemen dalam dinamika ketidakpastian lingkungan yang tinggi memberikan keleluasan bagi manajerial yang lebih tinggi.

Hasil penelitian ini sesuai dengan Faisal (2005) yang menyatakan besar kecilnya jumlah kepemilikan saham manajerial dalam perusahaan dapat mengindikasikan adanya kesamaan kepentingan antara manajemen dengan shareholders. Semakin meningkatnya 
proporsi kepemilikan manajerial maka akan semakin baik kinerja perusahaan sehingga manajer akan termotivasi untuk meningkatkan kinerjanya untuk perusahaan. Hasil penelitian ini tidak sesuai dengan penelitian Framudyo (2009) yang membuktikan kepemilikan manajerial tidak berpengaruh signifikan terhadap kinerja perusahaan.

\section{Pengaruh Antara Komite Audit Terhadap Kinerja Perusahaan}

Komite audit memiliki pengaruh terhadap kinerja perusahaan. Komite audit sebagai salah satu mekanisme corporate governance mampu mengurangi praktek manipulasi dan kecurangan dengan menjunjung prinsip corporate governance, transparansi, fairness, tanggung jawab, dan akuntabilitas yang pada prosesnya menghambat praktek kecurangan dan manupulasi dalam perusahaan. Pada penelitian ini komite audit mampu mengurangi praktek manipulasi dan kecurangan yang ada di perusahaan. Dengan adanya komite audit kepentingan-kepentingan tertentu yang membuat hasil laporan keuangan yang diterima oleh umum tidak sesuai dengan keadaan yang sebenarnya dapat diminimalisir. Pada akhirnya pelaksanaan corporate governance dapat meningkatkan kualitas laporan keuangan yang pada akhirnya mampu meningkatkan daya informasi akuntansi. Komite Audit mempunyai peran yang sangat penting dan strategis dalam hal memelihara kredibilitas proses penyusunan laporan keuangan seperti halnya menjaga terciptanya sistem pengawasan perusahaan yang memadai.

Hasil penelitian ini sesuai dengan penelitian Nasution dan Doddy (2007), bahwa keberadaan komite audit dapat menghambat terjadinya kecurangan dalam manajemen laba. Klein (2002) dalam Siallagan dan Machfoedz (2006), memberikan bukti secara empiris bahwa perusahaan yang membentuk komite audit independen melaporkan laba dengan kandungan akrual diskresioner yang lebih kecil dibandingkan dengan perusahaan yang tidak membentuk komite audit independen. Kandungan discretionary accruals tersebut berkaitan dengan kualitas laba perusahaan. Hasil penelitian ini tidak sesuai dengan penelitian Paramita Sari Rika (2008), menyatakan bahwa keberadaan komite audit dalam sebuah perusahaan tidak berpengaruh terhadap manajemen laba.

\section{Pengaruh Antara Leverage Terhadap Kinerja Perusahaan}

Leverage memiliki pengaruh terhadap kinerja perusahaan. Sumber dana perusahaan bisa berasal dari berkurangnya aktiva tetap, bertambahnya setiap jenis utang, bertambahnya modal, berkurangnya aktiva lancar selain kas, dan adanya keuntungan operasi perusahaan. Berpengaruhnya leverage terhadap kinerja perusahaan disebabkan oleh penggunaan utang. Penggunaan utang bagi perusahaan adalah untuk menitikberatkan pada besarnya jumlah jaminan atas kredit yang diberikan, dengan menggunakan utang maka perusahaan mendapatkan keuntungan lebih besar dari beban tetapnya maka pemilik perusahaan akan mendapatkan keuntungan yang meningkat dan 
penggunaan utang, perusahaan memperoleh dana dan tidak kehilangan pengendalian perusahaan. Berdasarkan hasil tersebut manajer perusahaan perlu menjaga tingkat hutang perusahaan karena apabila tingkat hutang baik, perusahaan akan efisien dalam meningkatkan keuntungan karena dengan tambahan modal yang ada dapat meningkatkan operasional dan kepercayaan investor. Selain itu, perusahaan dapat memberikan kepercayaan dan keyakinan kepada investor bahwa perusahaan dapat memanfaatkan semaksimal mungkin penggunaan modal eksternal dalam mengembangkan perusahaan dengan adanya peningkatan ROA. Apabila perusahaan meningkatkan nilai hutang jangka panjangnya untuk memfasilitasi segala aktivitas bisnis perusahaan, nilai keuntungan perusahaan juga akan meningkat. Namun peningkatan ini juga akan diikuti dengan peningkatan resiko.

Banyak penelitian membuktikan bahwa debt ratio untuk mengukur berapa besar aktiva perusahaan yang dibiayai oleh kreditur. Semakin rendah rasio hutang maka semakin bagus kinerja perusahaan, artinya asset yang dimiliki perusahaan sebagian kecil dibiayai dari hutang. Begitu juga sebaliknya, semakin besar rasio ini maka semakin buruk kinerja perusahaan, artinya asset yang dimiliki perusahaan sebagian besar dibiayai dari hutang (Sartono, 2011:54). Namun menurut Modigliani-Miller dalam Sartono (2011:236), perusahaan yang memiliki leverage akan memiliki nilai lebih tinggi jika dibandingkan dengan perusahaan tanpa memiliki leverage. Kenaikan nilai perusahaan terjadi karena pembayaran bunga atas utang merupakan pengurangan pajak dan oleh karena itu laba operasi yang mengalir kepada investor menjadi semakin besar.

\section{Pengaruh Antara Firm Size Terhadap Kinerja Perusahaan}

Firm size memiliki pengaruh tidak signifikan terhadap kinerja perusahaan. Hal ini menunjukkan bahwa ukuran perusahaan bukan jaminan bahwa perusahaan akan memiliki kinerja yang baik. Perusahaan dengan aset besar biasanya akan mendapatkan perhatian lebih dari masyarakat. Hal ini akan menyebabkan perusahaan lebih berhatihati dalam melakukan pelaporan keuangannya. Berbeda dengan perusahaan kecil yang tidak mendapatkan perhatian dari masyarakat. Tetapi dalam penelitian ini tidak ada perbedaan diantara perusahaan ukuran besar dan kecil. Perusahaan diharapkan akan selalu berusaha menjaga stabilitas kinerja keuangannya. Pelaporan kondisi keuangan yang baik tentu tidak serta merta dapat dilakukan tanpa melalui kinerja yang baik dari semua lini perusahaan.

Menurut Basir (2003), perusahaan dengan total asset yang besar mencerminkan kemapanan perusahaan. Perusahaan yang sudah mapan biasanya kondisi keuangannya juga sudah stabil. Selain itu, ukuran bank yang besar lebih diinginkan karena memungkinkan bank menyediakan menu jasa keuangan yang lebih luas. Hal senada juga diungkapkan Sudarmadji dan Sularto (2007), dimana perusahaan besar yang mempunyai sumber daya yang besar pula akan melakukan pengungkapan lebih luas dan mampu 
membiayai penyediaan informasi untuk keperluan internal. Informasi tersebut sekaligus menjadi bahan untuk keperluan pengungkapan informasi kepada pihak eksternal seperti investor dan kreditor, sehingga tidak memerlukan tambahan biaya yang besar untuk melakukan pengungkapan lebih luas. Dengan demikian, perusahaan yang besar mempunyai biaya produksi informasi yang lebih rendah daripada perusahaan kecil.

\section{Pengaruh Antara Jumlah Komisaris Independen Terhadap Kinerja Perusahaan}

Jumlah komisaris independen memiliki pengaruh tidak signifikan terhadap kinerja perusahaan. Tidak berpengaruhnya komisaris independen terhadap kinerja perusahaan disebabkan jumlah komisaris independen perusahaan sampel paling banyak berjumlah 1 orang, hal ini tidak efisien mengingat perusahaan sampel adalah perusahaan go public. Mengingat pekerjaan komisaris independen adalah memonitor proses pelaporan keuangan. Dewan komisaris harus berperan aktif, independen dan konstruktif. Nama besar, kemauan dan itikad baik belum cukup untuk membangun dewan komisaris yang berkualitas, dibutuhkan struktur, sistem dan proses yang memadai. Dewan komisaris independen bertugas melakukan pengawasan dan memberikan masukan kepada dewan direksi perusahaan. Dewan komisaris independen tidak memiliki otoritas langsung terhadap perusahaan. Fungsi utama dari dewan komisaris independen adalah mengawasi kelengkapan dan kualitas informasi laporan atas kinerja dewan direksi karena itu, posisi dewan komisaris sangat penting dalam menjembatani kepentingan principal dalam sebuah perusahaan.

Dewan komisaris yang independen secara umum mempunyai pengawasan yang lebih baik terhadap manajemen, sehingga mempengaruhi kemungkinan kecurangan dalam menyajikan laporan keuangan yang dilakukan oleh manajer (Chtourou, dkk: 2001) atau dengan kata lain, semakin kompeten dewan komisaris maka semakin mengurangi kemungkinan kecurangan dalam pelaporan keuangan. Penelitian Setyapurnama dan Norpratiwi (2007) menguji berbagai krakteristik dewan komisaris dan kelengkapan tata kelola yang mempengaruhi kemungkinan terjadinya kecurangan (fraud) di perusahaan Amerika. Hasil penelitian tersebut menunjukkan bahwa perusahaan yang persentase komisaris independennya rendah cenderung terjadi kecurangan. Penelitian Fuerst dan Kang (2004) menguji corporate governance dan kinerja operasi, menunjukkan adanya hubungan positif antara komisaris independen dengan kinerja perusahaan.

\section{CONCLUSION}

Hasil penelitian dan pembahasan yang digunakan sesuai dengan tujuan hipotesis yang dilakukan maka dapat ditarik kesimpulan sebagai berikut : 
1. Insider ownership berpengaruh positif signifikan terhadap kinerja perusahaan manufaktur di Bursa Efek Indonesia, dapat diartikan bahwa pergerakan kenaikan atau penurunan insider ownership diikuti oleh kenaikan atau penurunan kinerja perusahaan.

2. Komite audit berpengaruh positif signifikan terhadap kinerja perusahaan manufaktur di Bursa Efek Indonesia, dapat diartikan bahwa pergerakan kenaikan atau penurunan komite audit diikuti oleh kenaikan atau penurunan kinerja perusahaan.

3. Leverage berpengaruh positif signifikan terhadap kinerja perusahaan manufaktur di Bursa Efek Indonesia, dapat diartikan bahwa pergerakan kenaikan atau penurunan leverage akan diikuti oleh kenaikan atau penurunan kinerja perusahaan.

4. Firm size berpengaruh positif tidak signifikan terhadap kinerja perusahaan manufaktur di Bursa Efek Indonesia, dapat diartikan bahwa pergerakan kenaikan atau penurunan firm size tidak diikuti oleh kenaikan atau penurunan kinerja perusahaan.

5. Jumlah komisaris independen berpengaruh positif tidak signifikan terhadap kinerja perusahaan manufaktur di Bursa Efek Indonesia, dapat diartikan bahwa pergerakan kenaikan atau penurunan jumlah komisaris independen tidak diikuti oleh kenaikan atau penurunan kinerja perusahaan.

Sebagai bagian akhir dari penelitian ini, maka saran yang dapat disampaikan adalah hasil penelitian ini dapat dipakai sebagai acuan bagi peneliti selanjutnya untuk mengembangkan penelitian ini dengan mempertimbangkan variabel-variabel lain yang yang menjadi ukuran dari corporate governance, misalnya proporsi saham terbesar di perusahaan, dividen, komite remunerasi, risiko tingkat perusahaan, dan pertumbuhan ekonomi, karena variabel tersebut yang dipakaai dalam penelitian Krishna et al (2010). Selain itu penelitian selanjutnya hendaknya mengukur kinerja perusahaan dengan menggunakan variabel Tobin'q dan Market-To-Book.

Pada penelitian ini variabel insider ownership dan komite audit tidak berpengaruh terhadap kinerja perusahaan yang diukur dengan ROA. Adanya pengukuran Tobin'q dan MarketTo-Book dari kinerja perusahaan, diharapkan insider ownership dan komite audit memiliki pengaruh terhadap kinerja perusahaan. Bagi peneliti selanjutnya, hendaknya melakukan pengamatan pada sektor lain, seperti perusahaan tambang dan mineral, perusahaan jasa, perbankan dan sebagainya. Bagi manajemen sebaiknya mempertimbangkan firm size, dan jumlah komisaris independen dalam menentukan kebijakan karena variabel tersebut belum mampu meningkatkan kinerja perusahaan.

\section{REFERENCES}

Azhar Sina Austrindanney Ibnu. 2010. Pengaruh Good Corporate Governance Terhadap Profitabilitas Pada Perusahaan Go Public di Indonesia. Skripsi. Universitas Sumatera Utara.

Bapepam Nomor: Kep-41/PM/2003

Chtourou, S.M., Bedard, J., dan Courteau. 2001. Corporate Governance and Earnings Management. Working Paper. 
Effendi Arief. 2008. The power of Good Corporate Governance. Jakarta: Salemba Empat.

Fuerst, Oren dan Sok-Hyong Kang. 2004. Corporate Governance, Expected Operating Performance and Pricing. Corporate Ownership and Control (Winter): 13-30.

Gujarati, Damodar. 2000. Basic Econometric. Mc. Graw Hill: New York.

Hardikasari, Eka. 2011. Pengaruh Penerapan Corporate Governance Terhadap Kinerja Keuangan Pada Industri Perbankan Yang Terdaftar Di Bursa Efek Indonesia (BEI) Tahun 2006-2008. Skripsi. Universitas Diponegoro: Semarang.

Hiro Tugiman. 1995. Komite Audit. Bandung: PT. Eresco.

Husam, Aldamen., Keith Duncan., Simone Kelly., Ray McNamara., Stephan Nagel. 2012. Audit Committee Characteristics and Firm Performance During The Global Financial Crisis. Business Papers.

Krishna, Reddy., Stuart Locke., dan Frank Scrimgeour. 2010. The Efficacy Of PrincipleBased Corporate Governance Practices And Firm Financial Performance: An Empirical Investigation. International Journal of Managerial Finance Vol. 6 No. 3.

Kusumaning Linda, Wedari. 2004. Analisis Pengaruh Proporsi Dewan Komisaris dan Keberadaan Komite Audit Terhadap Aktivtas Manajemen Laba. Simposium Nasional Akuntansi VII, p 963-978.

Muchamad, Danu Septiyanto. 2012. Pengaruh Mekanisme Corporate Governance Terhadap Manajemen Laba Dan Pengaruhnya Terhadap Kinerja Perusahaan (Studi Empiris pada Perusahaan Manufaktur di BEI). Skripsi. Fakultas Ekonomi, Universitas Diponegoro, Semarang.

Mulyadi. 2001. Sistem Akuntansi. Edisi Ketiga. Cetakan Ketiga. Jakarta: Salemba Empat.

Nasution, Marihot dan Doddy Setiawan. 2007. Pengaruh Corporate Governance Terhadap Manajemen Laba Di Industri Perbankan Indonesia. Simposium Nasional Akuntansi X. Makassar 26-28 Juli.

Neely, Andy dan Adam, Chris. 2002. The Performance Prism: The Scorecard for Measuring and Managing Business Success. Pearson Education: London.

Paramita Sari, Rika. 2008. Hubungan Komite Audit terhadap Kinerja Keuangan Melalui Good Corporate Governance Sebagai Variabel Intervening. http//www:rac.uii.ac.id. Diakses tanggal 3 Maret 2014

Bambang Riyanto. 2001. Dasar-DasarPembelanjaan Perusahaan. Edisi Keempat. Yogyakarta: BPFG

Sartono, A. 2001. Manajemen Keuangan Teori dan Aplikasi. Yogyakarta: BPEFYogyakarta.

2011. Manajemen Keuangan Teori dan Aplikasi. Edisi ke Empat. Yogyakarta: BPFE.

Setyapurnama, Yudi Santara dan A. M. Vianey Norpratiwi. 2007. Pengaruh Corporate Governance Terhadap Peringkat Obligasi dan Yields Obligasi. Jurnal Akuntansi dan Bisnis. Vol. 7, No. 2.

Sudarmadji, Ardi Murdoko dan Lana Sularto. 2007. Pengaruh Ukuran Perusahaan, Profitabilitas, Leverage, dan Tipe Kepemilikan Perusahaan Terhadap Luas Voluntary Disclosure Laporan Keuangan Tahunan. Proceeding PESAT, Volume 2. 
Sutedi, Adrian. 2011. Good Corporate Governance. Jakarta: Sinar Grafika.

Taswan. 2003. Akuntansi Perbankan. Edisi Kedua. Yogyakarta: UPP AMP YKPN.

Waseem, Mohammad Yahya Al- Haddad., Saleh Taher Alzurqan., dan Fares Jamil Al_Sufy. 2011. The Effect of Corporate Governance on the Performance of Jordanian Industrial Companies: An empirical study on Amman Stock Exchange. International Journal of Humanities and Social Science. Vol. 1 No. 4.

Zarkasyi, Moh. Wahyudin. 2008. Good Corporate Governance. Bandung: Alfabeta.

Zubaidah, Zainal Abidin., Nurmala Mustaffa Kamal., dan Kamaruzaman Jusoff. 2009. Board Structure and Corporate Performance In Malaysia. International Journal of Economics and Finance, Vol 1, No 1.

Zunaidah, Sulong., John C. Gardner., Amariah Hanum Hussin., Zuraidah Mohd Sanusi., dan Carl B. McGowan, Jr. 2013. Managerial Ownership, Leverage And Audit Quality Impact On Firm Performance: Evidence From The Malaysian Ace Market. Accounting \& Taxation. vol. 5, no 1. 